\title{
Ornamentasi Seni Baca Al-Qur'an dalam Musabaqoh Tilawatil Qur'an sebagai Bentuk Ekspresi Estetis Seni Suara
}

\author{
Suryati \\ Jurusan Musik, Institut Seni Indonesia Yogyakarta \\ Jl. Parangtritis Km 6.5 Sewon Bantul \\ HP.085693460045, email: atik.jurasik@yahoo.com \\ G.R.Lono L.Simatupang dan Victor Ganap
}

Pengkajian Seni Pertunjukan dan Seni Rupa, Universitas Gadjah Mada Yogyakarta

\begin{abstract}
ABSTRAK
Ornamentasi atau hiasan merupakan suatu istilah musik yang memiliki arti penambahan beberapa nada atau notasi pada melodi, biasanya satu suku kata untuk beberapa nada yang disebut dengan istilah melisma. Ornamentasi atau hiasan nada sangat diperlukan dalam seni suara untuk memperindah suatu melodi. Ornamentasi melodi juga terdapat pada lantunan seni baca Al-Qur'an dengan gaya Qira'ah atau mujanwsad. Seni baca Al-Qur'an tersebut melagukan secara penuh melismatis dengan hiasan-hiasan atau ornamentasi melodi agar lantunan menjadi indah. Seni baca Al-Qur'an termasuk seni suara yang sering dilombakan dalam Musabaqoh Tilawatil Qur'an (MTQ). Penelitian ini mengkaji ornamentasi melodi dan cara-cara melantunkan seni baca Al-Qur'an dalam Musabaqoh Tilawatil Qur'an (MTQ), melalui pendekatan musikologis dan antropologis perilaku pelantun Al-Qur'an. Hasil penelitian ini menunjukkan bahwa ornamentasi yang terjadi pada lantunan seni baca Al-Qur'an dengan gaya Qira'ah merupakan bentuk ekspresi estetis seni suara dari Pelantun Al-Qur'an (Qori/Qoriah) sesuai kemampuan dan kreativitas pelantun dalam berolah vokal.
\end{abstract}

Kata Kunci: Ornamentasi, Seni Baca Al-Qur'an, Seni Suara

\begin{abstract}
Ornamentation the Art of Qur'anic recitation in Musabaqoh Tilawatil Qur'an as a Form of Aesthetic Expression of the Art of Sound. Ornamentation is a musical term that means adding a few notes or notation on the melody, normally one word for several notes known as the melisma. Ornamentation or ornamented notes are needed in the art of sound to reshape a melody. There are also additional melodic chanting on the art of Qur'anic recitation in the style the Qira'ah the mujawnad. The art of Qur'anic recitation practice in full melismatic with decorations or additional melodic chant in order to be beautiful. The art of Qur'anic recitation includes the sound art that is often competed in the Musabaqoh Tilawatil Qur'an (MTQ). This research examines melodic ornamentation and the ways art of Qur'anic recitation practiced in the Musabaqoh Tilawatil Qur'an (MTQ), through musikological and anthropological approaches to the behavior of in reading. The results of this study suggest that ornamentation piece of art that happens to read the Qur'anic in style is a form of aesthetic expression the art of sound of Qira'ah of its Chanter (Qori/Qoriah) fits the ability and creativity of chanter in doing the vocals.
\end{abstract}

Keywords: Ornamentation, The art of Qur'anic recitation, The art of sound

\section{Pendahuluan}

Seni merupakan salah satu kebudayaan yang lahir dan berkembang dari kehidupan manusia. Seni adalah penjelmaan rasa indah yang terkandung dalam jiwa manusia, yang dilahirkan dengan perantaraan alat komunikasi ke dalam 
bentuk yang dapat ditangkap oleh indera pendengar, indera penglihatan, atau dilahirkan dengan perantaraan gerak. Karya seni adalah bentuk ekspresi yang diciptakan melalui indra atau pencitraan dengan perasaan. Hasil karya seni dapat diwujudkan melalui ekspresi penghayatan estetis untuk memuaskan kebutuhan nalurinya akan keindahan (Malinowski, 1987:171).

Seni juga merupakan hasil ekspresi manusia yang tidak terlepas dari nilai-nilai keindahan yang dituangkan dalam berbagai bentuk yaitu seni suara, seni rupa dan seni gerak. Bentuk seni suara terbagai menjadi dua bagian yaitu seni sastra dan seni musik. Seni sastra meliputi prosa dan puisi, sedangkan seni musik meliputi musik vokal dan musik instrumental. Musik instrumental yaitu musik yang dihasilkan dari sumber bunyi alat-alat musik atau suara yang diperdengarkan melalui media alat musik, sedangkan musik yang dihasilkan dari sumber bunyi pita suara manusia hanya melagukan syair tanpa iringan musik disebut musik vokal atau seni suara (AL Baghdadi, 1991: 13).

Dalam Islam, puncak seni suara adalah tilawah Al-Qur'an sebagai suatu ibadah sunnah yang mempunyai banyak keutamaan (Munawwir, 1997: 471). Seni suara atau pujian kepada Allah selalu dapat ditemui sebagai sebuah ekspresi yang sungguh-sungguh baik di dalam maupun di luar masjid. Di Indonesia, lantunan ayat-ayat $A l$ Qur'an yang lazim disebut seni baca Al-Qur'an (Qira'ah) merupakan sebuah istilah yang memiliki arti 'mengeluarkan nyanyian liturgi (ghina), adzan (panggilan sholat), dan berbagai ragam nyanyiannyanyian religi rakyat yang banyak ditemukan di daerah-daerah kaum muslimin di seluruh wilayah tanah air' (Nurudin, 2015: 21).

Membaca ayat-ayat Al-Qur'an seperti yang disebutkan dalam Firman Allah: "Dan bacalah AlQur'an tartil." (QS. Al-Muzammil (73): 4), yang artinya membaca secara tenang, perlahan-lahan dan tidak tergesa-gesa, memperhatikan potongan ayat, permulaan dan kesempurnaan makna. Selanjutnya membaca Al-Qur'an dengan gaya murottal yaitu membaca Al-Qur'an yang memfokuskan pada dua hal yaitu kebenaran bacaan dan lagu Al-Qur'an. Kata murottal sendiri merupakan pengembangan dari kata ro-ta-la yang artinya tersusun rapi (Munawwir, 1997: 471). Gaya ini paling mudah dipelajari dan banyak dilantunkan oleh imam sholat karena tidak melagukan secara penuh atau tidak banyak ornamentasi melodi.

Seni baca Al-Qur'an (Qira'ab) adalah bacaan Al-Qur'an yang bertajwid diperindah oleh irama dan lagu atau dengan kata lain nagham, dapat dikategori sebagai jenis Handasah al-shaut atau seni suara (Al Faruqi, 1996: 475). Qira'ah berasal dari kata qira'at yang berarti pembacaan. Qira'ah merupakan salah satu seni baca Al-Qur'an yang dapat didengar hampir di setiap kesempatan, (dengan beragam pendengar di setiap sudut dunia Islam yang paling merasuk dalam budaya Islam.)

Seni baca Al-Qur'an gaya Qira'ab ini biasa disebut dengan gaya mujawwad yang artinya menjadi baik/bagus. Gaya tersebut melagukan secara penuh melismatis dengan hiasan-hiasan (ornamentasi melodi) agar menjadi indah. Ornamentasi melodi adalah suatu penambahan notasi pada melodi, dalam musik Barat ditandai dengan simbol-simbol. Ornamentasi atau hiasan-hiasan nada sangat diperlukan dalam seni suara untuk memperindah suatu melodi. Ornamentasi atau hiasan merupakan suatu istilah musik yang memiliki arti penambahan beberapa nada-nada atau notasi pada melodi, biasanya satu suku kata untuk beberapa nada yang disebut dengan istilah melisma (Taylor, 1989: 7), maksudnya seorang Qori/Qoriah maupun penyanyi melagukan dengan ornamentasi melodi pada satu suku kata dengan beberapa nada yang membentuk suatu rangkaian nada, dalam istilah bahasa Jawa dinamakan cengkok.

Seni baca Al-Qur'an ini merupakan salah satu yang dapat diterima di kalangan masyarakat luas. Hal ini dapat terlihat di seluruh masyarakat dari pelosok desa hingga seluruh Indonesia. Lantunan seni baca Al-Qur'an sering terdengar dalam suatu komunitas Islami baik dalam acara ritual keagamaan maupun pertemuan sosial. Di samping itu seni baca Al-Qur'an juga seringkali dipertunjukan dan dilombakan secara langsung 
dalam acara keagamaan dengan istilah Musabaqoh Tilawatil Qur'an (MTQ) dari jenis bacaan tartil, murottal, dan Qiro'ah (mujawwad) yang secara rutin diadakan setiap tahun baik dari tingkat daerah hingga tingkat nasional bahkan internasional dari berbagai kategori tingkat pelajar, mahasiswa, dan tingkat umum.

\section{Musabaqob Tilawatil Qur'an (MTQ)} terselenggara atas kerjasama Pemerintah Daerah dengan Kementerian Agama, baik daerah maupun pusat. Akan tetapi tidak mudah untuk bisa melantunkan ayat-ayat Al-Qur'an dengan baik dan benar, terutama jenis bacaan mujawwad, karena jenis bacaan tersebut terdapat liukan ornamentasi dalam seni baca Al-Qur'an. Untuk dapat mengamati dan mengkaji ornamentasi seni baca Al-Qur'an dalam Musabaqob tilawatil Qur'an diperlukan suatu metode deskriptif kualitatif pendekatan musikologis untuk ornamentasi yang terjadi pada seni baca $A l-Q u r^{\prime}$ an dan antropologis untuk perilaku cara-cara pelantun Al-Qur'an.

\section{Seni Baca Al-Qur'an dalam Musabaqoh Tilawatil Qur'an (MTQ)}

Lagu Al-Qur'an adalah alunan intonasi atau membaca yang disuarakan dalam keindahan alunan nada, variasi serta improvisasi selaras dengan pesan-pesan yang diungkapkan dalam ayat-ayat $A l-Q u r$ 'an yang dibaca. Lagu dalam seni baca $A l-Q u r$ 'an yang disuarakan bacaan kitab suci Al-Qur'an harus tunduk dan sesuai kaidah-kaidah tartil yang tertuang dalam disiplin ilmu tajwid serta makhrojul huruf yang benar. Seni baca $A l$ Qur'an atau nagham Al-Qur'an memiliki beberapa karakteristik yang berbeda-beda, yang sering ditampilkan oleh Qori/Qori'ah di masa kini yaitu; Nagham Bayati, Shaba, Hijaz, Nahawand, Sikka, Rasy, Jibarkah (Umam, 1987:108). Ketujuh maqam tersebut dapat kemas dengan beberapa tausyih untuk mempermudah dalam mempelajari seni baca Al-Qur'an. Setiap nagham Al-Qur'an tersebut memiliki ciri khas lagu/irama masingmasing terutama dalam tingkatan variasi nada Qarar/Nawa (suara rendah), tingkatan nada jawab (suara sedang) dan tingkatan nada jawabul jawab (suara tnggi). Adapun contoh tausyib bayati adalah sebagai berikut:

- Bayati Asli Tingkatan Nada Qarar

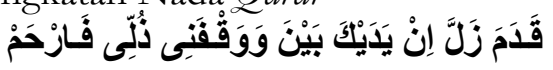

- Bayati Nawa Tingkatan Nada Qarar

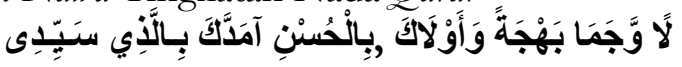

- Bayati Syuri Tingkatan Nada Qarar

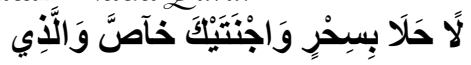

- Bayati Jawab I, Tingkatan Nada Jawab

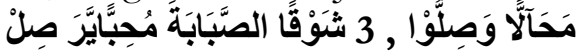

- Bayati Jawab II, Tingkatan Nada Jawab

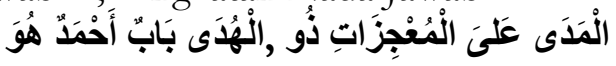

- Bayati Jawab III, Tingkatan Jawabul Jawab

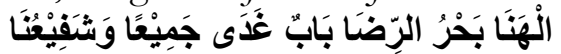

- Bayati Syuri, Tingkatan Nada Jawab

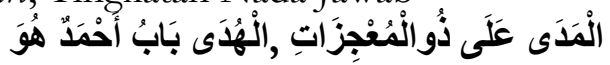

- Bayati Syuri Jawab, Tingkatan Nada Jawabul

Jawab

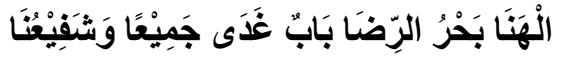

Berbagai macam seni baca Al-Qur'an atau nagham Al-Qur'an tersebut sering digunakan dalam Musabaqob Tilawatil Qur'an (MTQ), baik dengan gaya murottal maupun mujawwad yang diselenggarakan dan dipertunjukan secara langsung. Akan tetapi tingkat kesulitannya banyak ditemui dalam gaya mujawwad, karena harus memperhatikan ketepatan penerapan ilmu tajwid dengan ornamentasi melodi (melisma) dalam merangkai nada secara harmonis. Kreteria penilaian seni baca Al-Qur'an (Qira'ab) dalam Musabaqob Tilawatil Qur'an (MTQ) di samping tajwid harus benar juga dari nilai estetisnya. Dalam hal ini nilai estetis dapat dilihat dari keindahan alunan suara dalam lagu/irama, mad, panjang pendeknya harakat serta ornamentasi melodi. Adapun beberapa kreteria atau materi penilaian dalam MTQ adalah sebagai berikut.

1. Materi penilaian bidang tajwid, terdiri dari: Makharijul, Shifatul, Abkamul, Abkamul mad wal qoshr.

2. Materi penilaian bidang fashohah dan adab, terdiri dari: Al Waaf wal-ibtida, Muroatul kalimat wal kharokat, Muroatul kalimat wal ayat, Adabut tilawah. 
3. Materi penilaian bidang irama dan suara, terdiri dari: suara, irama dan variasi, keutuhan dan tempo lagu, serta pengaturan nafas.

Para Qori/Qoriah dituntut untuk mengekspresikan seni melalui membaca AlQur'an (Qira'ab) sesuai kemampuan dan kreativitas masing-masing dalam berolah vokal. Ornamentasi melodi atau liukan-liukan yang disebut dengan cengkok sangat berhubungan erat dengan ekspresi seni. Sebuah ornamentasi muncul sebagai salah satu bentuk perwujudan ekspresi seni yang estetis dan kreatif. Melagukan ataupun seni baca Al-Qur'an yang dilantunkan secara individu biasanya banyak dihiasi dengan ornamentasi melodi berupa liukan-liukan nada guna memperindah suara. Dalam membaca $A l$ Qur'an terutama pada gaya Qira'ab dituntut untuk menggabungkan keindahan suara dan akurasi bacaannya dengan irama tilawah-nya sekaligus (Qardhawi, 1998: 27).

Keberadaan ilmu nagham merupakan bagian yang tidak terpisahkan dari eksistensi manusia sebagai makhluk yang berbudaya yang memiliki cipta, rasa, dan karsa. Rasa yang melahirkan seni (termasuk nagham) merupakan bagian integral kehidupan manusia yang didorong oleh adanya daya kemauan dalam dirinya. Kemauan rasa itu sendiri timbul karena didorong oleh karsa rohaniah dan pikiran manusia. Secara terminologi, nagham dimaknai sebagai membaca Al-Qur'an dengan irama (seni) atau suara yang indah dan merdu atau melagukan Al-Qur'an secara baik dan benar tanpa melanggar aturan-aturan bacaan (Umam, 1987: 99).

Hasil perwujudan seni Islam yang dibentuk pada karakteritik-karakteristik tertentu, dapat terwujud antara estetika dan kreativitas. Dalam penilaian Islam bahwa segala bentuk seni selain merupakan ibadah juga mengandung dan menungkapkan nilai-nilai estetis. Seni Islam adalah seni yang dapat mengungkapkan suatu keindahan dan konsep taubid sebagai esensi aqidah, tata nilai dan norma Islam dalam menyampaikan keesaan Tuhan (Rizali, 2012: 4). Oleh karena itu, seni dalam Islam lebih menonjolkan kesucian yang bisa dilihat nilai estetiknya. Nilai estetik Islam sendiri lebih menonjolkan satu kesatuan bentuk yang berulang-ulang sehingga tercipta sesuatu yang harmonis dan seimbang. Keteraturan itu menggambarkan seni sebagai pengantar jiwa manusia kepada Tuhan-nya.

Berkaitan dengan hal tersebut, jika dimaknakan secara bahasa dikenal teori Islam antara vertikal (Hablumminallab) dan horizontal (Hablumminannas). Setiap ibadah yang diperintahkan Allah adalah untuk meningkatkan hubungan vertikal dan horizontal secara seimbang. Islam bukanlah agama yang memerintahkan untuk beribadah kepada Allah tanpa memikirkan kehidupan dunia, begitu pun sebaliknya tidak hanya mengejar kehidupan dunia. Akan tetapi setiap ibadah itu harus seimbang antara dunia dan akhirat. Sholat diawali dengan takbiratul ihrom dan diakhiri dengan salam yang mendo'akan seluruh makhluk yang ada di bumi ini. Artinya dalam bacaan sholat pun ada hubungan antara Allah dan sesama manusia.

Teori vertikal kaitannya dengan seni baca Al-Qur'an (Qira'ah) adalah aqidah dan ibadah di antaranya: adzan, sholat, baca Al-Qur'an, bahwa mempunyai keyakinan untuk ibadah mendekatkan kepada Allah. Adapun teori horizontal dalam kaitannya dengan seni baca $A$ Qur'an (Qira'ab) adalah logika, etika dan estetika. Secara logika, perilaku seni baca Al-Qur'an harus menurut kaidah yang dapat diterima oleh masyarakat seperti yang tercantum dalam kriteria penjurian dan tata-tertib lomba Musabaqob Tilawatil Qur'an (MTQ) dengan rumusan dan pakemnya yang baku. Etika dalam membaca $A$ Qur'an salah satunya tampak melalui teknik vokalisasi yang harus menutup aurat, sebagai contoh tidak membuka mulut lebar-lebar, suara lebih diarahkan ke hidung menjadi suara nasal. Estetika dalam seni baca Al-Qur'an (Qira'ab) dapat dilihat dari teknik ornamentasi berupa alunan melismatik dari suku kata yang memperoleh aksentuasi menurut panjang pendeknya nada, liukan-liukan motif melodi, hiasan-hiasan atau ornamentasi yang memperindah perjalanan alur melodi. 
Berbeda halnya dengan membaca $A$ Quran sebagai seni berarti membaca Al-Quran dengan maksud untuk menikmati keindahan iramanya. Membaca Al-Quran sebagai seni tidak menuntut pemahaman, setiap orang yang menguasai cara membaca huruf Arab bisa mengekspresikan keindahan seni suara secara musikal dari ayat-ayat Al-Quran. Berkaitan dengan estetika Islam, dalam bukunya yang berjudul The Cultural Atlas of Islam, Ismail R. AlFaruqi menyatakan:

This orientation and goal of Islamic aestetics could not be achieved through des-cription of man and nature. It could be realized only through the contemplation of artistic creation the would lead the participant to an intuition of the truth itself that Allah is so other than His creation as to be unrepresentable and inexpressible (1986:163)

Lebih lanjut Al-Faruqi mengatakan bahwa kitab suci Al-Qur'an merupakan perwujudan yang sempurna unik dari keluhuran sastra, telah ikut mempengaruhi kesadaran estetis setiap umat Muslim. Pengaruh estetis tersebut adalah i'jaz. AlQur'an, sastranya (balaghab), dan seni rupa. Dalam seni rupa, yang lebih tampak terutama seni kaligrafi, seni dekorasi, dan motif sajadah. Selain itu, berpengaruh juga pada seni suara, yakni seni baca Al-Qur'an, adzan, dan semua bentuk suara manusia maupun bunyi instrumen. Berkaitan dengan hal tersebut, maka dapat dikatakan bahwa nilai-nilai estetis dalam Islam bersumber dari Al-Qur'an. Al-Faruqi juga menegaskan bahwa Al-Qur'an merupakan karya seni yang pertama dan terutama dalam Islam (1986:223). Oleh karena itu, pengaruh Islam dalam seni, merupakan bagian dari kebudayaan yang sangat ditentukan oleh ekspresi estetis keislamannya (Sutrisno, 2011: 25).

Dalam Islam, nilai atau sifat keindahan yang ditimbulkan haruslah mengekspresikan nilai ibadah, yaitu mencari ridho Allah dan memiliki manfaat bagi pembentukan nilai-nilai akhlak atau budi pekerti yang mulia. Penciptaan bentuk-bentuk yang mengandung nilai estetika berpadu dengan nilai estetika Islam dan estetika Islam itu ialah akhlak.

\section{Ornamentasi dalam Seni Baca Al-Qur'an (Qiro'ah)}

Dalam sebuah komposisi musik, terutama pada periode Barok dan Klasik, banyak ditemui ornamen-ornamen musik. Ornamen yang dimaksud adalah not-not yang ditambahkan pada sebuah melodi, tidak termasuk nilai not melodi dan tentu tidak termasuk dalam birama. Sejumlah ornamen ditandai dengan simbol yang standar dalam notasi musik, sementara ornamen lain dapat ditambahkan dengan not kecil, atau hanya ditulis secara normal. Beberapa jenis ornamentasi tersebut diantaranya; Trill, Morden, Gruppetto, Appogiatura, dan Acciaccatura yang kesemuanya itu dapat dinotasikan dalam notasi balok.

Adapun ornamentasi atau hiasan dalam musik Barat terlulis sebagai berikut:

1. Trill adalah pergantian yang cepat antara notasi pokok dan satu notasi di atas.

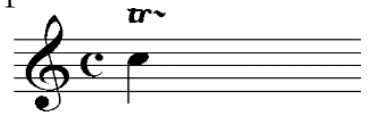

cara memainkannya

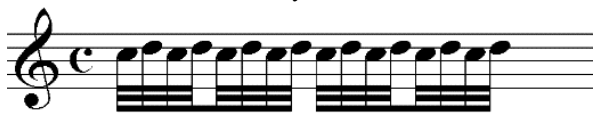

2. Morden adalah terdiri atas notasi pokok dengan notasi di atas atau notasi di bawah, kemudian kembali ke notasi pokok lagi.

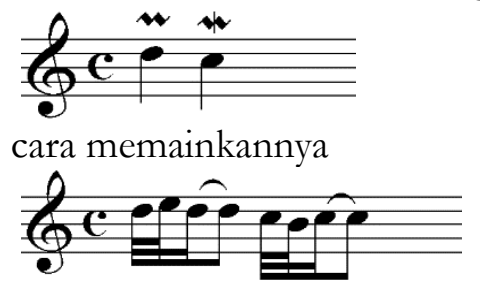

3. Gruppetto adalah terdiri atas notasi dasar, notasi di atas, notasi dasar lagi dan notasi di bawahnya.
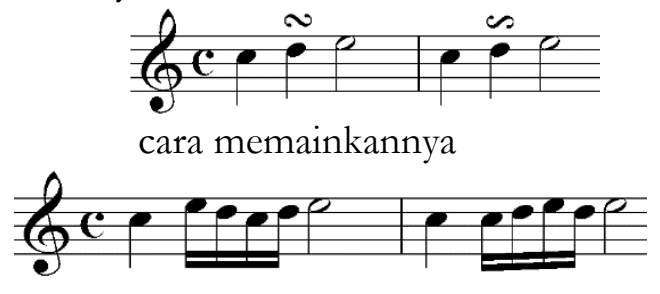
4. Appogiatura adalah notasi yang bentuknya lebih kecil dari notasi dasar dan umumnya mendapat sebuah aksen. Nilai notasi Apopggiatura mempunyai nilai separuhnya dari notasi dasar.

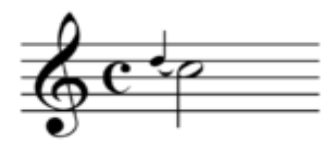

cara memainkannya

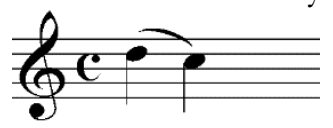

5. Acciaccatura ditulis seperti Appoggiatura, tetapi diberi tambahan garis kecil menyilang pada tangkai notasinya. Aciacatura biasanya akan dimainkan secara cepat dengan notasi sepertiga puluh dua.

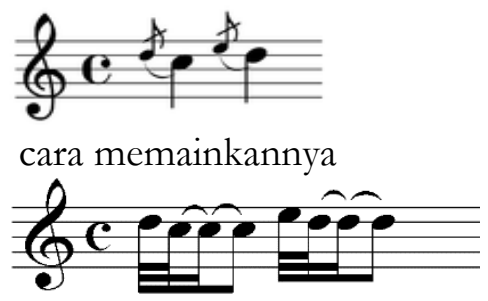

Pada umumnya ornamentasi yang terjadi pada musik Barat sudah terstruktur dan tertulis secara sistematis di dalam partitur lagu. Selain itu terdapat jenis ornamentasi melodi (melismatik) pada lagu-lagu Gregorian yang berkembang pada abad pertenganhan, yang notasinya sudah tertulis pada partitur lagu. Oleh karena itu, seorang penyanyi dalam menyanyikan lagu tersebut sesuai pada partitur lagu yang panjang pendeknya nilai notasi dan tanda sukat sudah ditentukan. Lagu-lagu tersebut pada umumnya dinyanyikan hanya satu suara dan dipakai dalam ibadat Kristiani (Prier, 2009: 58). Adapun contoh ornamentasi melodi musik Barat yang berupa alunan melismatik pada lagu Gregorian adalah sebagai berikut.

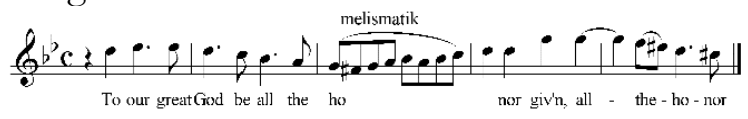

Ornamentasi yang terdapat dalam seni baca Al-Qur'an (Qiro'ah) berbeda dengan ornamentasi yang terdapat pada musik Barat.
Qori/Qoriah dalam melantunkan Al-Qur'an memberi ornamentasi berdasarkan pengalaman, kemampuan berekspresi dan kreativitas masingmasing, karena ornamentas pada seni baca $A l$ Qur'an (Qiro'ab) tidak tertulis secara terstruktur. Oleh sebab itu, ekspresi dan pengalaman memiliki hubungan dialektis yaitu ketika "pengalaman menstruktur ekspresi" maka begitu juga sebalinya "ekspresi dapat juga menstruktur pengalaman” (Mistortoify, 2014:14). Pada dasarnya ornamentasi seni baca Al-Qur'an dapat dituliskan dengan simbol-simbol atau pakem tersendiri untuk memudahkan cara belajar seni baca Al-Qur'an terutama yang mujawwad.

Seorang Qori/Qoriah dalam MTQ selain harus melantunkan Al-Qur'an sesuai ilmu tajwid juga menunjukkan kemampuan berolah vokal dengan memberikan liukan atau cengkok. ornamentasi secara penuh berdasarkan harmonisasi nada sebagai bentuk ekspresi seni dari seorang Qori/Qoriah. Cengkok merupakan nada-nada hias (ornamentasi) yang berbentuk rangkaian melodi tersusun secara harmonis. Melodi-melodi cengkok tersebut biasanya ditemukan pada nada-nada yang berdurasi panjang misalnya durasi $1 \frac{1}{2}, 2,2$ 1/2, dan 3 ketukan yang dihasilkan secara improvisasi. Tanpa adanya jiwa seni dan pengetahuan tentang harmonisasi yang baik, seorang Qori/Qoriab tidak akan bisa mengekspresikan seni suara dalam seni baca Al-Qur'an dengan baik. Liukan atau cengkok. ornamentasi dalam seni baca Al-Qur'an biasanya terletak pada akhir kalimat atau pada huruf hidup yang rangkap/panjang, sebagai contoh dalam ayat "Bismillabirrahmaanirrabiim" suku kata terakhir "biim" dapat memberikan beberapa nada seperti halnya nada melisma. Namun panjang ornamentasi melodi sesuai kemampuan Qori/Qoriah bisa dua harakat, tiga harakat ataupun empat harakat.

Ornamentasi pada seni baca Al-Qur'an mengikuti nada-nada yang ada dalam tausyih atau bait-bait syair dengan gerakan-gerakannya. Gerakan tersebut seperti gerakan holpen suara yaitu gerakan dalam frekuensi sekali atau dua kali, dan triller suara yaitu gerakan suara dalam frekuensi tiga atau empat kali. Akan tetapi 
gerakan tersebut tetap toleransi terhadap potensi gerakan suara pembaca. Demikian pula nadanada tinggi, sedang, dan rendah yang relatif panjang dalam kalimat-kalimat pada bait-bait syair juga tetap toleransi pada saat diterapkan ke dalam ayat-ayat $A l-Q u r$ 'an sesuai kebutuhan yang dituntut oleh pembaca terutama dalam konteks lirik-lirik lagu untuk suatu ayat. Panjang pendeknya ornamentasi melodi atau rangkaian nada-nada dalam seni baca $A$ l-Qur'an ditentukan dengan harakat, jadi lebih luwes, bebas, dan hikmat dalam mengekspresikannya, terlebih pada tingkatan nada jawab dan tingkatan jawabul jawab sangat leluasa dalam berekspresi. Berkaitan dengan melantunkan Al-Qur'an secara baik, bagus dan memberikan ornamentasi melodi yang harmonis sesuai tinggi rendahnya nada, maka sangat diperlukan suatu teknik pernafasan yang baik.

\section{Penutup}

Ornamentasi seni baca Al-Qur'an dalam Musabaqob Tilawatil Qur'an (MTQ) memiliki ciriciri serupa dengan dengan gejala ornamentasi secara musikologis meskipun tidak sama persis. Ornamentasi di dalam musikologis tertulis secara sistematis, sedangkan ornamentasi seni baca $A l$ Qur'an tidak tertulis. Akan tetapi secara penempatan dan rangkaian melodi memiliki tinggi renadah, serta harmonisasi yang hampir sama, yaitu dalam satu suku kata dengan beberapa nada yang disuarakan secara melismatik. Ornamentasi atau hiasan melodi pada alunan seni suara baik dalam menyanyi maupun seni baca Al-Qur'an (Qiro'ab) yang mujawnwad berfungsi untuk memperindah alunan suara.

Ornamentasi lagu Gregorian dinyanyikan oleh seorang penyanyi yang satu dengan yang lain hasilnya akan sama, karena sudah tertulis pada part lagu. Berbeda dengan ornamentasi pada seni baca Al-Qur'an (Qiroah) yang mujammwad dari seorang Qori/Qoriah yang satu dengan yang lainnya tidak tentu sama, karena improvisasi nada-nada berdasarkan pengalaman estetis, pengetahuan, kemampuan berekspresi dan kreativitasnya Qori/Qoriah masing-masing.
Hal ini juga sangat dipengaruhi dari teknik caracara melantunkan Al-Qur'an dengan baik dan benar.

Seni baca Al-Qur'an mujawnwad pada Musabaqob Tilawatil Qur'an (MTQ) merupakan seni suara yang dipertunjukkan secara langsung, maka sangat erat hubungannya dengan ekspresi, estetis, dan kreativitas terutama dalam mengekspresikan sebuah ornamentasi melodi di setiap ayat-ayat yang dilantunkan. Tanpa adanya ekspresi yang estetis, ornamentasi pada seni baca Al-Qur'an tidak menghasilkan suara yang baik dan indah. Hal ini merupakan salah satu kreteria atau materi penilaian dalam MTQ. Oleh karena itu, dapat dikatakan bahwa ornamentasi yang terjadi pada seni baca $A l-Q u r$ 'an dalam Musabaqob Tilawatil Qur'an merupakan hasil eskpresi seni suara dari pelantun Al-Qur'an atau Qori/Qoriah.

\section{Kepustakaan}

Al-Baghdadi, Abdurrahman. 1991. Seni dalam Pandangan Islam. Jakarta: Gema Insani

Al-Faruqi, Isma'il Raji. 1999. Seni Taubid: Esensi dan Ekspresi Estetika Islam. Yogyakarta: Bentang.

Al-Faruqi, Ismail and Louis-Lamya. 1986. The Cultural Atlas of Islam. New York: Macmillan Publishing Company.

Beg, M. Abdul Jabar. 1988. Seni di Dalam Peradaban Islam. Bandung: Pustaka Bandung.

Boulata, Isa. 2008. Al-Qur'an yang Menakjubkan: Bacaan Terpilib dalam Tafsir Klasik bingga Modern dari seorang Ilmuwan Katolik. Jakarta: Lentera Hati.

Chatibul Umam, Muammar ZA, Maria Ulfah. 1987. Belajar Membaca Al-Qur'an dengan Lagu. Jakarta: Lembaga Bahasa dan Ilmu Al-Qur'an.

Hadi WM, Abdul. 2004. Hermenentika, Estetika, dan Relegiusitas, esai-esai Sastra Sufistik, dan Seni Rupa. Yogyakarta: Mahatari.

Hosein, Omar Amin. 1979. "Al Qu'ran Sebagai Sumber Penciptaan Seni musik" (terjemahan dan saduran dari karyanya 
"Kultur Islam") dalam Serial Media Dakwah-No. 63. Jakarta, 36-41.

Isma"il Al-Faruqi dan Lois Lamya Al-Faruqi. 1996. Atlas Budaya Islam.Kuala Lumpur, Malaysia.

Malinowski, 1987. “Teori Fungsional dan Struktur" dalam Koentjaraningrat, Teori Kebudayaan I. Jakarta: Universitas Indonesia Press.

Mistortoify, Zulkarnain, dkk. 2014 "Pola Kelleghan dan Teknik Vokal Kejhungan representasi Ekspresi Budaya Madura dan Pengalaman estetiknya" dalam Jurnal Resital, Jurnal Seni Pertunjukan Vol. 15 No. 1. Yogyakarta: Galangpress.

Nelson, Kristina. 1982. "Reciter and Listener: Some Factors Shaping the Mujawwad Style of Qur'anic Reciting", Ethnomusicology vol. XXVI.

Nurudin Triyasyid. 2015. Pedoman Tajwid Mudan dan Aplikatif. Kartasura Solo: Taujih.

Prier, Karl-Edmund. 2009. Kamus Musik. Yogyakarta: Pusat Musik Liturgi.
Qardawi, Yusuf Al-. 2002. Fiqh Musik dan Lagu; Perspektif Al-Qur'an dan As-Sunnah. Bandung: Mujahid Press.

Sutrisno, Langen Bronto. 2011. "Pengaruh Islam dalam Kesenian Setrek di Magelang", dalam Jurnal Resital, Jurnal seni Pertunjukan Vol. 12 No 1. Yogyakarta: Galangpress.

Rasmussen, Ann K. 2010. Women, The Recited Quran, and Islamic Music in Indonesia. USA: University of California Press. --. 2001.“The Qur'aan in Indonesian Daily Life: The Public Project of Musical Oratory". Ethnomusicology Vol 45, No.1 Winter.

Rizali, Nanang. 2012. "Kedudukan Seni Dalam Islam”, dalam Jurnal TS $A Q A F A$, Jurnal Kajian Seni Budaya Islam Vol. I. Yogyakarta: Pustaka Pelajar.

Taylor, Eric. 2004.The ABC Guide to Music Theory (Part II). London: The Associated Board of the Royal Schools of Music. 